archives-ouvertes

\title{
The Autumn of the Nahda in Light of the Arab Spring: Some Figures in the Carpet
}

\author{
Leyla Dakhli
}

\section{To cite this version:}

Leyla Dakhli. The Autumn of the Nahda in Light of the Arab Spring: Some Figures in the Carpet. Cambridge university press. Arabic Thought beyond the Liberal Age, 1780s-1940s: Towards an Intellectual History of the Nahda, 2016. < halshs-01247587>

\section{HAL Id: halshs-01247587 https://halshs.archives-ouvertes.fr/halshs- 01247587}

Submitted on 22 Dec 2015

HAL is a multi-disciplinary open access archive for the deposit and dissemination of scientific research documents, whether they are published or not. The documents may come from teaching and research institutions in France or abroad, or from public or private research centers.
L'archive ouverte pluridisciplinaire HAL, est destinée au dépôt et à la diffusion de documents scientifiques de niveau recherche, publiés ou non, émanant des établissements d'enseignement et de recherche français ou étrangers, des laboratoires publics ou privés. 


\title{
CHAPTER 12
}

\section{The Autumn of the Nahda in Light of the Arab Spring: Some Figures in the Carpet}

\author{
Leyla Dakhli, CNRS, University of Aix-Marseille ${ }^{1}$
}

To embark upon writing the history of the contemporary Middle East, particularly its intellectual history, Albert Hourani is a necessary and precious companion. In a way, he has always been with me, conversing with me, as I write. He was finishing his work as I was starting mine, and in this way I did not personally know him. But saying this is not simply to claim myself an "heir" to a founding figure, or to claim to have a full grasp on my indebtedness to him. Rather, it is to designate the field of Middle East research as a terrain for continued conversation.

This chapter is a conversation with Hourani's work on the intellectual and cultural history of the contemporary Arab world. It aims to access the fissures in what Hourani called "Arabic thought" in order to propose new research areas. Above all, this article seeks to reveal what it is we expect today from the writing of a history, not of Arab thought, but of Arab intellectuals. In this sense, Arab thought is produced by professionals of words, and can be considered as an activity which is situated in the social system.

\section{Writing intellectual History without the West}

For Albert Hourani, the West of was a way to access the modernity of certain strains of thought in the 19th and 20th centuries. It acted as a mirror held out the Arab world, constantly

\footnotetext{
${ }^{1}$ I would like to thank Jens Hanssen for his close and insightful reading of this chapter. The English translation was done by Jill McCoy, whom I deeply thank, and was founded by the French National Agency for Research, through the LabexMed Program (projet Investissements d'Avenir A*MIDEX / ANR-11-IDEX-0001-02).
} 
presented by the intellectuals themselves either as a foil or as a goal to strive towards. In this sense, Hourani's Arabic Thought in the Liberal Age, can be thought of as a product of its time: the 1950s and early 1960s were fraught with the paroxysms of the Cold War, during which the newly independent states of the Arab world, having been a playing field for colonial powers, emerged as a site of resistance against the old world powers while struggling for non-alignment.

Looking back at his own attempt to write his more or less exhaustive text on Arab thought, Hourani criticized the bias of his own vantage point regarding "what was liberal" at the time. He objected to his tendency to focus on thinkers who were "influenced by the West." The way he formulated it, however, his objection misconceives of the problem in terms of an intellectual world divided into "borrowed" and "authentic" ideas. In "How Should we write the History of the Middle East?" Hourani confessed:

It now seems to me to have been wrong in laying too much emphasis upon ideas which were taken from Europe, and not enough upon what was retained, even if in a changed form, from an older tradition. ${ }^{2}$

This opposition between what was "taken from Europe" and what was "retained from an older tradition" is a general index of the horizons and circulations attributed to thought. Such a conception must be put in the context of Hourani's own desire to describe "Arabic thought:" an object with an autonomous life brought into full relief in intellectual debates, particularly among individuals. 'Thought' is, in a way, caught between tradition and Europe. It is a choice without room for alternatives; not even in terms of the history of ideas itself. New thought coming from within is inconceivable, and the capacity for non-European thought to emerge in response to imperial categories is doomed to inauthenticity or traditionalism. Above all, such

\footnotetext{
${ }^{2}$ Hourani in IJMES (1991: 128).
} 
an understanding of intellectual history neglects the crucial factor of society. Posing the question of how to write Middle East history in these terms is to define Arab societies as places of tradition, whereas the West - the omnipotent Other - is conceived of as the modern, the new, and the source of change. Hourani discovered social history after writing Arabic Thought and abandoned his history of ideas project altogether.

In the above-quoted article, Hourani spoke of a "great stable society." "Is this the result of the historiographical blind spot in which Hourani began his research on the preWorld-War-I Middle East, or is it rather the unconscious effect of a culturalist reading?

Difficult to say. What I am sure of, however, is that writing Middle East history today means destabilizing such oppositions in order to re-imbue society with its capacity for invention. We may consider borrowings and references from Europe and the West as transformations, hybridizations, or self-examinations from a strategic location of distance.

To adopt oppositions like tradition and modernity, stability and transformation and map them onto geopolitical constructs like the West and the East, inevitably prioritizes certain breaks and differentiations over others. The problematics of gender, religious affiliation, and the secular/non-secular dichotomy emerge as a function of the clash between modernity and tradition. These binaries are often combined and tend to define, on the one hand, a liberal, more Christian, more feminist and more secular world of the Nahda and, on the other hand, an opposing, Muslim world of reform, masculinity, and religion. Beyond these designations lurks "society" stuck in the throes of an ageless immobilism. Of course, I am overstating the point. Hourani's text also showed that there are links between Muslim reformers grappling with religious traditions and Nahda thinkers who engaged in literary history, European genres, the translations of Western works, and secular values. ${ }^{4}$

\footnotetext{
${ }^{3}$ Ibid., 129.

${ }^{4}$ See also Hamzah (2012: 90-127).
} 
This synthetic approach has a drawback, however, in that it contributes to scholarly underrating of generational gaps and ruptures in modern Middle East history. Research agendas that set out to reveal the continuity of transmission, social status and position (religious affiliation, education, the possibility for travel), ends up labeling a given thinker as either modern or traditional. And yet, since the late $19^{\text {th }}$ century, intellectual and political movements around the Mediterranean identified themselves as "young" - Young Ottomans and Young Turks, Young Arabs, Young Algerians, and Young Tunisians). Even though criticizing one's elders does not constitute good etiquette in the Middle East, every generation since the Nahda has found its footing in critically assessing, discreetly as well as openly, the record of their forbears. Starting over again, transmitting and repeating are leitmotivs in Arab intellectual history. Clean breaks - when they are articulated - originate elsewhere, and then predictably in the West. I do not want to make generational breaks more radical than they were. However, it is possible to identify generational consciousness by paying attention to the way the intellectuals transform what they borrow from abroad, the experience of travel, the influence of translation, the effect of religious conversion, and by studying the social conditions under which their works were created more generally. ${ }^{5}$ Hourani's work may be read as the tale of the adventures of two generations of intellectuals. One of the central texts he analysed in Arabic Thought was Farah Antun's treatise on Ibn Rushd, which called for secularization and was written in the spirit of the "new shoots of the East." ${ }^{\prime 6}$ Hourani accounts for the dispute that erupted between him and Muhammad Abduh in a typical history-of-ideas fashion:

The choice of subject shows the influence on Antun of Ernest Renan [who had written a widely circulated account of the excommunicated Islamic philosopher, Ibn Rushd $\left.{ }^{7}\right]$. He had translated Renan's Vie de Jésus, and now, in writing of Ibn Rushd, he was

\footnotetext{
${ }^{5}$ Makdisi (2008); see also Dakhli (2012).

${ }^{6}$ Hourani, La Pensée arabe et l'occident (1991d: 264).

${ }^{7}$ Renan (1852).
} 
following a path marked out by his master. The general views which he expounds are roughly those of Renan, although without the seduction of his master's voice, of that extraordinary style, limpid, moving, and not quite serious.

The reader cannot help but admire Renan and consider Antun a second-rate, derivative thinker obsessed more with imitation and Western recognition than with the urgent context in which he was intervening. Antun argued, Hourani continued, that "[ $t]$ he 'conflict' between science and religion can be solved but only by assigning to each its proper sphere... this sounds innocent enough, but such ideas, injected into a society organized on the basis of adherence to revealed religions, could have revolutionary implications." First impressions of the Arab thinker are confirmed by the immobilism of the society from whence he hailed. The response of Abduh, whose syncreticism Hourani idealized in a chapter dedicated to this Islamic reformer, was anger at the decidedly Christian undertones of Antun's secularism. For Abduh, "religion, if purified, could still serve as the basis of political life, and was in fact the only solid basis." ${ }^{8}$ The quality of Antun's or Abduh's arguments concerns me much less than the way Hourani - and many other after him - framed the debate. The revolutionary potential of Antun was discredited by his apparent intellectual slavery to his European master and by his exilic condition which estranged him from an adequate understanding of Arab society. Hourani's Abduh, by contrast, held the centre and represented Arab social trends and cultural values more truthfully.

To reduce Arab cultural critics to Western intellectual influences the way Hourani framed Antun, is no less problematic than reducing them to their religious affiliation. Only when we pay attention to concrete intellectual practices may we add further complexity to this chain of oppositions. How we handle sources is key to escape this chain. Marilyn Booth has

\footnotetext{
${ }^{8}$ Hourani (1991d:266).
} 
shown us how literary, epistolary and archival sources can index intellectuals as social actors and not mere knowledge transmitters. "Minor works" of Nahda writers can help us understand representations, attitudes, and modes of being in the world that were far from stable.

Reframing intellectuals as social actors bring to light individuals and social trends that were invisible or marginal in Hourani's account. Among these relatively unheard voices, there are first and foremost the women. And among them, there has been a tendency to favor the women who held salons or who were lovers and partners of 'great men.' This has been at the expense of those whose activities did not leave a paper trail. For me, the point of articulating intellectual ruptures and fractures in my continued dialogue with Hourani is not simply to construct a historical reading of the Nahda that differs from his. Rather, I offer a re-reading that may come close to a new understanding of the Zeitgeist of Hourani's "liberal age.",10

\section{Beyond "the condescension of posterity" and "the tyranny of globalizing}

\section{discourses"}

We live in an age of history-making surprises in the Middle East. Active social and political minorities sought empowerment and have created historical breaches. They have expressed desires for emancipation that few ascribed to the West or to the East. Most commentators at the time have agreed that the Arab uprisings constituted a generational eruption against authoritarian immobilism. They have also shown the importance of the sense of failure, political disillusionment, and hesitation for protecting the contested Zeitgeist of the revolutionary moment from what Hourani's contemporary, E. P. Thompson, once called "the

\footnotetext{
${ }^{9}$ In this sense, work such as that of Marilyn Booth, the result of exacting research of language and literature, tends in a promising and fruitful direction. See Booth (2001 and 2008).

${ }^{10} \mathrm{I}$ am thinking of the kind of intellectual history, Hourani's near-contemporary, Carl Schorske has produced in his Fin-de-siècle Vienna (1980).
} 
enormous condescension of posterity." ${ }^{11}$ Our writing of Arab intellectual history, then, needs to be situated consciously in its particular time and place. For periodizing and labeling intellectual history - "the liberal age," "the age of reforms," or "the age of revolutions" - is posterity's epistemological choice.

Such historical tensions and historiographical temptations also apply to a good part of feminist thought and action during the interwar period in the Middle East when the social, literary and scientific experimentations of numerous intellectual outsiders captivated the spirit of the age. And if today some of these experiments seem to us to have gone against the grain of historical change, the fact remains that they indeed occurred. They make it possible to write a social history of intellectuals that makes room for the 'losers'.

Given the over-representation of the region's political and geo-political history, sensitive intellectual history requires that we make space for the micro-history of those figures whose activities are obscured by the global scale of inquiry. Zooming in and out of historical perspectives reveals the complexity of multiple social worlds. Multi-scalar inquiry also discloses Henry James' famous "figure in the carpet” which is hidden in the embroidery of everyday life. In the words of Pascale Casanova, Henry James's well-known phrase serves to characterize the figure that appears only when its "form and coherence are suddenly seen to emerge from the tangle and apparent disorder of a complex composition ... by looking at it from another point of view.",12

It seems to me that Hourani's question of how to write history should be superseded by the question of "for whom," or "to what end?" This may appear out of fashion, obsolete, or too committed, but it may help to write the history of an embattled society where a culture of defensiveness pervaded. ${ }^{13}$ To interrogate historical sources to find out what they reveal about the society they emerged from, as well as to navigate the spaces where "subjected

\footnotetext{
${ }^{11}$ E. P. Thompson (1963/1991: 12).

${ }^{12}$ Casanova (2005: 3).

${ }^{13}$ See Foucault (1997).
} 
knowledge" and the "historical knowledge of struggle" emerge, may help end what Foucault considered "the tyranny of globalizing discourses." 14 Expressing the problematique in these terms is, evidently, to suggest that all history is engaged, that it is a response to questions of the present, and speaks always of the present moment. It also suggests that historical research is a dialogue with the here and now - an instrument made to arm and to provide memory to those who "burst forth" with speech. The question of "to what end do we write history?" leads to a new series of new questions.

The development of knowledge about the contemporary Arab world and its own historical evolution drives me, as a historian, to approach the decisive Foucaultian point: the point at which history becomes a "problem." The history-problem neither seeks to write the history of one particular period for its own sake nor judge it with the benefit of hindsight. It consciously works with snippets in attempts to understand problems of our contemporary times and lives. As Foucault writes:

Whoever chooses to deal with a «problem » that arises at a given moment must follow other rules - choosing material based on the nature of the problem, focusing the analysis on elements likely to solve it, and establishing relations that make this solution possible. And so one must remain indifferent to the obligation of saying everything, even just if it is to satisfy the jury of specialists present. ${ }^{15}$

The problem here is to grasp the figure of contemporary intellectuals in the Arab world - to understand how their lives and works are interwoven with the society that produced them, and to recognize their capacity for social and political change against the odds of censorship, enforced education systems, and the denial of freedom of speech and assembly on Arab societies. Under such conditions, how has the transnational history of Arab thought - travel,

\footnotetext{
${ }^{14}$ Foucault (1994: 165).

${ }^{15}$ Foucault (1980: 32).
} 
exile and, now, social media - navigated adversity and opened up alternative social spheres and norms in and outside the Middle East? These questions turn the history of Arab intellectuals into a global history. Here, Edward Said represents an Arab intellectual figure whose attempt to grapple with his experience of exile as a Palestinian-American has transformed the way we conceive of global intellectual history. ${ }^{16}$ Living and working in the West no longer constitutes the delegitimizing position that Hourani accorded to Farah Antun, for example.

\section{Writing History with the Arab Revolutions}

At the beginning of their armed uprising against the Assad regime, Syrian rebels often named their battles after heroes of revolts against the French mandate on the iconic Friday demonstrations. By turning toward anti-colonial and national memory - memories of the great Arab Revolt of 1925 for example - they created a new insurgent repertoire of combat. ${ }^{17}$ In Tunis, the rebels chanted slogans they made up in the streets, also drawing on relatively recent moments in the history of social protest, but often without realizing it - there were no handbooks of the struggles of 1968, 1978, or 1983. Old combat flags reappeared on the streets. Some people waved them unaware of their historical meanings and rallied around them as if for the first time; others perceived in their current fight the echo of struggles from the past that were fought by their fathers and mothers. Nostalgic perceptions of the Tunisian uprising were particularly common among bloggers writing from the diaspora and among artists who hailed from families which were politically active in the 1960s. Such invocations of history during the Arab uprisings challenge the guarded script of "the transition to democracy." The transitional, open-ended nature of the revolutionary moment - the creative process - requires a different optic and temporal analytic. The events that took place under

\footnotetext{
${ }^{16}$ In particular, see Said's memoires (2000).

${ }^{17}$ Since these early days, Islamist and sectarian repertoires have taken over.
} 
our own windows, encouraged me as participant observer, historian and social and political actor, to reflect on time as matter in motion. At times, events moved with breath-taking speed, at other times agonizing inertia seemed to prevail. Those heady days in December/January 2010/11, challenge our understanding of the order and causes of change. Are deep historical structures or global events the triggers of revolution? Or is it the minor, local and immediate ones that shake the world $?^{18}$ And who decided what is a major and what is a minor event in world history, anyway? It is precisely in these differences and in this uncertainty that I look to locate the writing of history ${ }^{19}$. It is not necessary to privilege marginal figures, that is, to locate oneself on the edge. Rather, the road is windy and one must mind the blind spots.

In what follows I offer two case studies of two Syrian intellectuals of one generation who adopted different strategies to address the same problematic in interwar Bilad al-Sham the family and women. These case studies approach are part of a larger attempt to cross temporal and spatial borders with intellectuals and activists from the contemporary Arabic world. The historical situation and the intellectual positions of a generation of intellectuals in

early $20^{\text {th }}$ century Bilad al-Sham illuminate the complex inter-relations between public sphere and private concerns, liberty of thought and gender expectation.

\section{Entrapments of Mandate Feminism: society and family as a "history-problem"}

Foucault's idea, and one that I would like to pursue here in relation to intellectuals, is that scientific discourses produce truths that in turn consecrate power. Dichotomies, rationalizations, and categories are obvious determinants, but often discourse takes a more complex form, sometimes more militant at others appearing as neutral. Discourse presented as "scientific" conceals more spontaneous knowledge originating from the personal and social

\footnotetext{
${ }^{18}$ Dakhli (2011: 89-103).

${ }^{19}$ Dakhli (2013).
} 
practices of its authors. Arguably, then, we can extract from 'scientific' texts, the concrete conditions of production of knowledge.

I have chosen to concentrate on two Syrian figures through the lens of two works. These two texts were billed as scientific analyses with firm grips on questions of a social, even intimate nature, and in two distinct registers of scientific literature.

Kazem al-Daghestani (d. 1980) was born in Damascus in 1900 and hailed from a family with a stellar record in the Ottoman service. The left for Paris in the late 1920a to study sociology at the Sorbonne. His doctoral dissertation was published in 1932 and dealt with Syrian family structure and transformation. ${ }^{20}$ Nazira Zayn-al-Din (1908-1976) published her bombshell work, al-Sufur wa-l-hijâb (Unveiling and Veiling) on the full-body veil in 1928. ${ }^{21}$ Both of these intellectuals belonged to the category of politically-inclined "young writers" ofwhat Keith Watenpaugh has defined as "the generation of 1900."22 Unlike some of their peers' grand-standing, they presented their social critique in a seemingly meek and sober fashion. Daghestani developed his argument from a sociological and anthropological perspective. Zayn al-Din's approach was more classical and exegetical, but she was no less worldly.

Certain elements of their biographies set them apart from each other despite the fact that they both came from well-established families. The most obvious difference is, of course, gender and their respective social positions. Kazem was the first male child in a large family and is therefore invested with expectations and the family name. He went to study in Paris thanks to the financial stability of his family and the freedom it allowed him to enjoy. Nazira was a very young woman when she published her book. She came from a family which

\footnotetext{
${ }^{20}$ Daghestani (1932).

${ }^{21}$ Zayn al-Din (1928) was generously reviewed by, inter alia, Henri Lammens in Machriq 26 (1928), 366-74; 'Ali ‘Abd al-Razziq, al-Hilal (August 1928), 1190-92, and was mentioned in Toynbee's 1928 Survey of International Affairs (London: RIIA, 1928), 204. Today sections of it have been translated in Badran and Cooke (1990) and Kurzman (1998). For a biography of Nazira Zayn al-Din, see Cooke (2010).

${ }^{22}$ Watenpaugh (2006: 225-30).
} 
valued the principles of emancipation, but society denied women the same freedoms as men. For a woman of her age, her courage and confidence are astonishing. And yet, she did not present herself in conflict with the order of things, but rather stresses the continuity that drove her, a continuity best reflected in the act of dedicating the book to her father and in paying continual homage to her predecessors throughout. At the start of the book she declared:

I ask the sirs to please not accuse me of disturbing the peace or of looking to escape from wearing the veil, for that is not what I have done. It is in fact my father, your brother - whom God created completely free, and who is not afraid, in the name of justice, to attract the eyes of critics - it is he who freed my from this prison in the name of God's justice and in the interest of family and society. It is he who took into consideration the growth of my mind and the breadth of my education, and sent me off on this voyage to discover life and light. ${ }^{23}$

For Daghistani, it was a voyage to Paris and for Zayn al-Din a voyage in the realm of knowledge. Both their departures coincided with a desire to understand, to learn, and to make others understand. The positivist quest for knowledge was a topos shared by the entire literary class at the time, and especially by women, who saw it as the key to potential freedom. As early as 1888, Aisha al-Taymuriyya had exclaimed in the introduction to her book, The Results of Circumstances in Words and Deeds: "How my eyelids overflowed with tears because I was deprived of harvesting the fruits of their beneficial learning! What hindered me from realizing this hope was the tent-like screen of an all-enveloping wrap." ${ }^{24}$ Indeed, the headscarf was seen as an obstacle in the quest for science.

According to most traditional criteria of the literary and intellectual fields, these two texts, published within a few years of each other, were remote from one another. "Al-Sufur

\footnotetext{
${ }^{23}$ Zayn al-Din (1928: 59).

${ }^{24}$ Cited and translated in Badran and Cooke (1990: 127).
} 
wa-l-hijab"was a classic theological treatise written in the conventional format for this kind of text - the tafsir. It draws upon a detailed reading of the Koran and its commentaries in order to argue against the wearing of the full-body veil. To make her case, Nazira uses istishhad, that is, she cites textual authorities that counter conventional arguments. But beyond the classic form of the book and beyond the unique situation of the young female theologian, Nazira's work was radical and rebellious in content. Its argumentation was decidedly feminist and combative, and the theological treaty she is presenting is one of a very distinctive personal voice. She instrumentalized the authorities she cited by using their research to draw opposite conclusions on individual freedom, the individual's responsibility to God and human equality. Moreover, the interests of the family and society were not as values per se but were rooted in the education of a sense of justice.

These values guided her faith as much as her argumentative style. For her, the Muslim religion was capable of emancipation, both for men and women. One of the arguments she stressed in particular was the necessity for men and women to have confidence: "What is this life, then, your life, if in your own home you have enforced a law that goes against your mother, daughter, and sister, out of fear that they might betray you?"25

She supported her arguments with extensive historical research on the status of women during the time of the prophets. This is where she made the case for emancipation and action, including violent struggle, citing the figure of Jeanne d'Arc as the prominent example of women's and human liberation. ${ }^{26}$ But her argument against the full-body veil also came in the name of social equality - the veil is the symbol of a particular social class, essentially of urbanites. One social class must not seize Islam and Islam's corresponding way of life at the expense of others, she wrote. Her argumentation was strongly nationalist. She went into great lengths to juxtapose Muslim and Western cultures' in terms of emancipation, development,

\footnotetext{
${ }^{25}$ Ibid., 125 .

${ }^{26}$ Ibid., $159-162$.
} 
and success. At one point, she addressed a fictitious sheik, a representation of tradition at its most obstinate, to whom she demonstrates that the desire to "uphold" tradition was merely a way of denying Muslims any future. ${ }^{27}$

Unveiling and Veiling did not qualify as part of the "traditional" scholarship. It clearly differed from other Quran exegeses, not just because it was the first full tafsir to be published by a woman on the delicate question of the veil. It was also initially recognized by some leading ulama and intellectuals. The founder of the Arabic Academy in Damascus, Muhammad Kurd 'Ali, for example, ordered twenty copies for its library; the editors of the Saida journal al- 'Irfan accorded a favourable reception of the book when it first came out; the Sunni scholar Taqqi al-Din al-Sulh invited her to deliver a lecture at the Arab Literary Association that he chaired in 1928. Behind its tafsir façade, the book was modernist in the way it mobilized critical thought and called for action to defend women's rights. Zayn alDin's treatise responded to a particular deterioration in the freedom of women. In 1927, the Damascene parliament was discussing a decree to prohibit women from walking in the streets of the souk without face cover. ${ }^{28}$ She entered the controversy and took her stand:

As soon as I began to understand the meaning of law, liberty, the independence of the will, the autonomy of thought, insufficiency, and even the inadequacy of imitating tradition in religion, I started to study the East and particularly the question of women. What I saw in my studies did not satisfy me, and many things displeased me. But most of the time I kept my feelings to myself. Last summer, in Damascus, the freedom of female Muslims was threatened when we were forbidden to walk outside without a veil and enjoy the air and light. It was then that I took my pen and decided to express what I had been containing within me. And my pen, guided by my own spirit, began to

\footnotetext{
${ }^{27}$ Ibid.

${ }^{28}$ Thompson (2000: 136).
} 
scramble along on the paper, and my poor troubled spirit demanded more and more demonstration. $^{29}$

The decision to publish the fruits of her research therefore stemmed from her engagement for Muslim women. Writing was the result of an overflow of "feelings", and through writing she found a form of relief, even healing. The treatise appears as a remedy, both a personal remedy and a remedy for society's woes. Zayn al-Din's social project crystallized here: free thought, freeing thought, shall take primacy over blindly imposed norms and traditions.

At the end of the 1920s, the intellectual sphere was not a stable, calm terrain on which she could move about as she pleased. The atmosphere was tense; it was politically charged. Unnerved by Nazira's writings, the "shuyukh" - the group of Islamic scholars defended their privileges and religious interpretations by launching personal attacks against her. They could have accepted the 'feminine discussions' on the veil and its impact on health that appeared in the magazines. They could also deal with the Kemalist propaganda that was ubiquitous on the walls of Damascus. But Nazira wrote a whole treaty, she was invoking the Quran! Their goal was to nip in the bud the wave of female emancipation and any signs of feminist destabilization. They directly attacked the upper classes and the bourgeoisie, who, after a long period of protecting societal mores and traditional values, were in the process of Westernization and transformation in the presence of colonial powers. These classes, her detractors claimed, were led astray by to following in the footsteps of Atatürk who abolished the Caliphate, created a republic, and - to boot - ordered women to remove their veils.

Zayn al-Din did find inspiration in the Turkish ruler and invoked a famous quote of his in her response to her critics, al-Fatat wa-l-shuyukh, in 1929: "My clean victory over the enemy is partly thanks to my soldiers and partly to the veils which have been ripped away

\footnotetext{
${ }^{29}$ Zayn al-Din, al-Sufur wa al-hijab, 39.
} 
from the faces of women." ${ }^{30}$ Zayn al-Din was born in Istanbul as the child of the Young Turk revolution and the daughter of a modernist conception of the world wherein progress was located in secularization. She possessed at once the religious education given to her by her father and the curiosity engendered by an engagement with the Enlightenment: she knew European languages and frequented missionary establishments like the Catholic French speaking school of Saint-Joseph-de-l'Apparition and the Sisters of Nazareth Convent School and the Lycée Français Laïqu. By contrast, conservative Muslim officials categorically rejected the colonial presence. These conservatives looked with suspicion to the notable conservatives of the Syrian National Block who had ambitions to rule the region. As a matter of strategy, they increasingly focused on questions of identity: customs, cinema, fashion, leisure, as they targeted the ruling elite and mobilizing the popular neighborhoods against the modern disease of "fasad" - or depravity and corruption. ${ }^{31}$ These tensions take a violent turn when it is reported that certain non-veiled women have been attacked with acid in the streets. ${ }^{32}$ As positions grew more rigid, the reactionary shuyukh went on the offensive. The shuyukh claimed they represent the religion of the majority - the common people. They were engaged in a noble fight against the modernist elite who, unable to prevent colonization and its misdeeds, pretended to fight for independence but actually adopt the colonial powers' very same values and enemies. Nazira's book was at the centre of an open battlefield. This fight was the direct continuation of what happened during the Great Arab revolt in Syria a few years earlier. As the Syrian national movement was forced to negotiate with the French Mandate authorities to keep its power, the populists were opening new frontlines in society. This was the time when Kazem al-Daghestani, the young Syrian student in Paris, decided to work on the family structure in his native country.

\footnotetext{
${ }^{30}$ Al-Fatat wa-l-shuyukh, p. 56.

${ }^{31}$ See Dakhli (2009).

32 Thompson (2000: 136); see also Tresse (1939: 120).
} 
Kazem al-Daghestani's monograph dealt with this subject of religion and social norms. It radiated scientific sobriety. Written in French it did not contribute immediately to the political debates raging in the aftermath of al-Sufur wa al-Hijab. The Orientalist scholar Maurice Gaudefroy-Demombynes attested to the scholarly objectivity of the text in the book's preface, and Daghestani himself insisted on the point in the few first of his introduction:

This text aims to describe, with the most possible objectivity, several current aspects of Sunni Muslim families in Syria (...) Whatever this work may be missing, we ask that you not believe it is the mere fruit of circumstance, or the result of curiosity that some scholars are beginning to express on the subject here at hand. ${ }^{33}$

The young aspiring academic sought intellectual legitimacy by presenting his work as an original piece of scholarship intended to fill a gap in existing knowledge. Daghestani's study reads as a meticulous description of the customs and traditions of marriage, conjugal life, parent-child relationships, and familial relationships more generally speaking. The data is based on observations and discussions as well as frequent, playful incursions into popular speech and proverbs. No direct mention is made of contemporaneous debates surrounding marriage or feminist protesting, except in a brief exposé of the various existing theses. ${ }^{34}$

The only book by a female author which Daghestani cited in his meticulously assembled bibliography was Nazira Zayn al-Din's. Other works by male authors engaged in the fight for the emancipation of women were also listed: Jamil Bayhum's al-Mar'a (Beirut, 1926) and the Egyptian Mansour Fahmi's thesis, La condition de la femme dans la tradition et l'évolution de l'Islam (Paris, 1910). It is no coincidence that Daghestani chose to take up the delicate question of familial ties and rights. As a young student in Paris, he was attracted to sociology and anthropology as means for national intellectuals to provide new insights and

\footnotetext{
${ }^{33}$ Daghestani (1932).

${ }^{34}$ Ibid.,126, note 1.
} 
knowledge on their own environment, society and identity. The whole debate on the veil and the condition of women was so salient and violent at the end of the 1920's that most of the young secular intellectuals were convinced that they had to address these questions urgently. Before writing his thesis, Daghestani met another important figure of the women's emancipation, Marie 'Ajami, with whom he became a very close friend and colleague during their work for al-Mizan (1925-1927). This journal was founded by the combative and creative Damascene intellectual Ahmad Shakir al-Karmi ${ }^{35}$ Daghestani was a very active contributor to the newspaper, and was frequently in charge of translating pieces of French authors of social sciences, especially articles from Les Annales.

Daghestani's chapter on the wearing of the veil made reference to Zayn al-Din's text in a section entitled "The Veil and its Imposition on Young City-Dwelling Women."36 Before summarizing the various intellectual positions, the author alerted the reader that "the question of removing the veil is a current issue in Syria and it is discussed passionately everyday and in almost every single family. ${ }^{, 37}$ In his account, the veil debate was seen foremost as a sociological question of a set of dichotomies between the city and the countryside and between the upper and lower classes. Daghestani avoids completely the religious dimension. Instead, he limits himself to a discussion of the different elements, describing the conservative ulama's point of view and their desire not just to impose the wearing of scarves but also to "revive obsolete practices." ${ }^{38}$ He did not further develop the idea but one can understand that he is making a difference between the simple application of a religious duty and the revival of old - 'obsolete' - practices. The problem for him was not religion but progress and modernity.

\footnotetext{
${ }^{35}$ Dakhli (2005 and 2009).

${ }^{36}$ Daghestani (1932: note I, 126).

${ }^{37}$ Ibid., 128.

${ }^{38}$ Ibid. For more on this debate on the veil, see Dakhli (2010).
} 
Though Daghestani presents his work as more “objective" than his fellow writers', there existed a palpable tension between them. This dialogue reveals very different social and personal positions within the same "modern" intellectual elite class. Zayn al-Din's decision of writing no doubt stemmed from her own real engagement, as a woman, in the theoretical question she puts up for debate. The issue for her is tangible, just as it is for all women. And her engagement is perceptible, for her treatise also served as an address for a group, a "they" that the author identified in her next text as the sheiks (al-shuyukh). Her words were visceral and aimed against the "illiberals", to borrow Amal Ghazal's term in this volume.

Daghestani's “objectivity” position was a result of his distance and gender, but it was also a chosen spatial distance with regards to the debate and the ensuing social tension. He wrote from Paris, after having worked in Syria for some years. The author nevertheless felt the danger, and identified it in the normative dichotomies of modernity and tradition. Newspapers from the years 1928-1930 regularly reported on attacks carried out on women in the souks of Syrian cities. The conservative sheiks' counter-offensive was clearly more than rhetorical. The conclusions of Daghestani's work underline the contradictions between law, norms, and social traditions. Just as Nazira emphasized the contradictions between the desire to liberate a nation and the desire to subjugate women, so Kazem demonstrated that Islamic law, which he dismissed as inert and "obsolete", was not the only cause of the most problematic traditions continuing to be upheld. He wrote:

Many facts and customs remain outside the realm of law without being consolidated and made uniform by legal rules, and this creates a veritable pathological state wherein dangerous consequences for the nation's future are becoming more and more flagrant. ${ }^{39}$

\footnotetext{
${ }^{39}$ Daghestani (1939: 211).
} 
Towards the end of his study, Daghestani described a tension-ridden society, where the city was pitted against the country and the nomad against the sedentary population. He called on the state to resolve these tensions by imposing strong laws. In light of these conclusions and policy recommendations, the work may be seen as the result of an Orientalist and colonialist reading of the state of affairs in the area. Like the colonial authorities, Daghestani lamented the position of women but believed that the force of modernity as embodied in the state had the power to bring change and combat archaic traditions. Once he returned to Syria, Daghestani assumed a more directly involved position in order to improve the condition of women. His writing style also changed, he switched to Arabic, and he focused instead on autobiographical fiction. In a certain regard, this new type of writing drew on his sociological research, but it is based more on personal narrative, revealing social and familial tensions in a livelier and, often, more amusing fashion. ${ }^{40}$ The Arabic autobiographical novel Daghestani wrote at the end of the 1960s revisits elements of anthropological analysis: the author describes a large Damascene family with all of its idiosyncrasies and manias (women living together, jealousy, the attention the male attracts), but also with all of its urban customs (like the rooftop pigeon flights and its special meaning in al-Sâlhiyyeh, his Damascene neighborhood. $^{41}$

Nazira's and Kazem's writing style and personal engagement were very different, but both aimed to describe a reality they wished to see evolve toward more equality and individual freedom. Both chose scientific manners of expression and both demonstrated that they belonged to a system of intellectual recognition. However, the approach remained more existential for Nazira. Her work is recognized and supported by a certain number of scholars, but she pursued her studies in a relatively isolated manner. Kazem, on the other hand, was a man enmeshed in the world of letters wrote in newspapers, gave lectures, and participated in

\footnotetext{
${ }^{40}$ al-Daghistani (1969).

${ }^{41}$ Ibid., 81-85.
} 
literary and journalistic projects in Arabic and in French. Their intellectual worlds appear distinct and apart and yet, they launch a similar social critique. This convergence cannot be explained by a general internalization of the West's epistemological hegemony. Reading the two texts together, it becomes much more complicated to situate tradition and modernity, the modern Western world and the traditional East. Both Kazem and Nazira had deep knowledge of languages and read a wide range of diverse literatures. They write these two texts within a specific scientific code (a thesis, a treaty), inside a specific horizon d'attente and they are both very careful not to exceed or transgress these codes. But they bring to the academic their mixed culture. They also wrote in times of transition and engaged with the debates, the social tensions and contradictions of the time.

The tensions of urban society during these years came into sharp relief in their texts which reveal their respective positions. These were the years that the Muslim Brotherhood in Egypt came into being, and the same years that the most conservative branch of the religious hierarchy tightened its grip on Syrian Muslim community. This is not the place to analyse the diverse branches of conservative thought and politics. Suffice it to note the phenomenon of a new radical Islamic thought in Bilad al-Sham whose populism was quite different from the reformist agenda of the preceding decades, but also from the "illiberals" of Yusuf alNabhani's ilk that Amal Ghazal's chapter in this volume discusses. The notions of national struggle and "returning" to religion became intertwined in these quarters. The emerging conservative 'ulama and political leaders endowed religious attributes with new national and nationalist significance. The conflict's violence is even more clearly felt in Nazira's writing, for she was attacked, ridiculed and vilified in the sheikhs' responses. Even if some allies continued to support her, the reformists were now split, and began to hedge their bets on the 
question of women. Her book's main target, Shaykh Mustafa al-Ghalayini (1886-1944), was a friend of her father's who read and responded to her book. ${ }^{42}$ He was an 'alim of the old days, who defended religious reforms within a conservative framework. For Nazira, Ghalayini was more a personal opponent than a mortal enemy. Her enemies did not get into the intellectual debate, they were more active on the streets in parliaments and mosques where they launched moral condemnations and physical attacks against women. The end of the 1920's, as Elizabeth Thompson suggested, witnessed a new "polarization between secular nationalists and religious populists." ${ }^{43}$ In this battle, the religious elite that was linked to the nationalists could not find its place. They despised populism as much as secularism.

Kazem al-Daghestani shared the same torments as Nazira. Syrian parliamentary politics of the dominant National Bloc was his natural political habitat, but over the din of political battles it became more and more difficult for "moderates" like him to be heard. Once they entered into the political sphere, the notables wished to protect their privileges, and to do so they felt they had to mollify society and its representatives. Among them were sheikhs and moralizers of many shapes and sizes. Given his position as an educated intellectual from a family of high standing, Kazem, like others, found himself at bay. Kazem had a great concern for social justice, and this lead him to consider that scientific writing was the only way of getting involved, as the legal and constitutional battles were in full swing and charged with tension. Women's struggles for their rights, inspired by progress observed most notably in Turkey, were well received by the notables but ultimately, they were sacrificed, in the name of national tradition, by the wielders of power. The two authors here have in common not only their belief in scientific method - he sociology, she tafsir- , but also in their belief in science's universality. In the face of contradictions with regard to the values of authenticity and the fight against imperialism, they turned to science and its capacity for liberation. Nazira

\footnotetext{
${ }^{42}$ al-Ghalayani (1928).

${ }^{43}$ E. Thompson, Colonial Citizens, 138.
} 
responded to the sheiks who accused her of colluding with the enemy ran along these lines: "the best way to build the best schools for Arabs and Muslims is to copy the best foreign schools and universities like Oxford, the Sorbonne, Columbia, Princeton and Harvard where minds are freed to soar into the open sky enlightened by new knowledge and attentive to the illuminating forces God gave them, purified of the germs of diseases or worn-out customs that are a disaster for the East." 44 As Kurzmann reminds us, "the distinctiveness of the modernists lay in seeing modernity as a promising avenue for cultural revival (even if they) disagreed vehemently among themselves as to the extent to which cultural revival must erase existing cultural forms." 45

This analysis of the end of the 1920s and the beginning of the 1930s, as well as the particular situation of these two writer-thinkers leads us to a reexamination of the theoretical questions posed by Hourani on the absence of "traditional" thinkers in his work, or the scant place he accords to "illiberals." Just like the intellectuals he had studied for so long, he refused, in a way, to see them, because they were not as innovative and eminent in the time he labeled the 'Liberal Age'. Their supposed intellectual weakness made them invisible in the same way the modesty of their audiences and disciples was. Instead, it was the people's religion - a religion of superstitions and moral rigidity, according to the secular thinkers as well as the Islamic reformists - that came to compensate for paltry theory. Nazira's stance exuded a similar arrogance. She was unreservedly sure that she was right. The publication of her response to the sheikhs who had criticized her, al-fatat wa-l-shuyukh, was redolent with bitterness. She was very confident in her position and her knowledge. Armed with the praise she has received, the "young girl" Nazira reassured herself of the things she knows for sure. All the while, however, her position vacillated and she was not truly able to understand why. By publishing her private thoughts in her book, she entered public debates and was suddenly

\footnotetext{
${ }^{44}$ Zayn al-Din, Al-Fatat wa-l-shuyukh (1929: 60); translated in Cooke (2010: 95).

${ }^{45}$ Charles Kurzman, (1998: 11).
} 
facing something quite different from the intellectual jousts of her father's mansion. She was confronted with the social tensions and the political fights the realm of ideas generated.

Locked in complex historical and political positions, Kazem al-Daghestani and Nazira Zayn al-Din's works also shared the fate of being celebrated and then quickly forgotten. Commentators have often referred to them as "ahead of their time." But this formula presupposes a problematic "sense of history." In reality, both thinkers - along with many intellectuals - were out of sync with their age. Their texts were situated at the heart of major discussions on the potential of independence and modernity. They called to transform society and common rules of life challenged the very foundations of social cohesion. Believing it possible to think up an alternate future for their own situation and their own freedom - for Nazira, the freedom of being a young educated woman, for Kazem the high social position, the academic recognition in France, and the freedom of being male - they failed to problematize the extent to which their sense of freedom was a class privilege. This blindness to their own subjectivity stripped the purported universality of their arguments of their legitimacy. This is also why they never thought of contesting colonial rule. Even more, they did validate the presence of colonial French rule against their own society and national loyalty. Nazira sent a copy of his book to the French High Commissioner Ponsot with a special dedication, asking him, of all people, to free the woman from the veil. Kazem was far more critical of the Mandate, but he was a real admirer of the French language and culture, and thought that it was possible, even in a colonial context, to separate the wheat from the chaff. Neither writer ever had the sense that there was some kind of a betrayal in these positions. 
Hourani's project of writing the history of Arab intellectuals helps the contemporary historian-intellectual to engage in self-reflexive, action-oriented scholarship. Raising consciousness of the intellectual's place in the Arab world yesterday in light of today, raises the question of the social utility of the historian who tells the tales of forgotten lives, stories of struggle and exile, generational solidarities, emancipations, and imprisonments. Kazem alDaghestani and Nazira Zayn al-Din's questions in the 1920s and 1930s ring true with contemporary discussion on the rules of personal status in Muslim countries, on the conflicts between civil and religious categories, ${ }^{46}$ and on the different forms of female emancipation in Islam. These questions are posed within the context of changes taking place in the authors' respective territories.

Albert Hourani was himself one of the actors and one of the gatekeepers in the history I have set out to write. So are others who have attempted to cover the same historical terrain, both Arab and non-Arab. Hourani's students, disciples and opponents, both senior and junior, and the political and institutional positions which are invested in the project of contemporary intellectual history, build on or contest Hourani's legacy. ${ }^{47}$ One of the steps along the way of this project was our conference at Princeton in October 2012 that led to this book. And though Hourani worked essentially in Great Britain, his history is pursued at American Middle East centers and departments, especially as a new generation of Arab-American historians are emerging and addressing new searching questions to the history of the Arab world, to Orientalism, and to academic knowledge production worldwide.

As a Franco-Arab historian, my intention is not to remain aloof from these AngloAmerican developments in Middle East history. I aim to participate in the conversation as well, not least because Hourani's influence extended south of the Channel, too. I am a historian, born in Tunisia, a child of bilingual intellectuals with working-class background,

\footnotetext{
${ }^{46}$ On questions of sectarianism at the time, see Weiss (2010).

${ }^{47}$ Al-Sudairi (1999); see also Owen (1997) and Piterberg (1997).
} 
reared on knowledge and the love of books - but also nurtured by the idea of a possible emancipation in the Arab world and elsewhere. I did not come to my research by chance. For like Hourani, I was provided with an official story, and with family stories in multiple languages. But none has provided a satisfying template to give, with Judith Butler, an account of myself. ${ }^{48}$ Rather, the complexity and 'truth' that have formed me both intellectually and as a person owe a debt to the work of Edward W. Said. ${ }^{49}$

Michel Foucault taught philosophy in Tunis and witnessed the riots of 1968 of Tunisia just before those of Paris. He observed the richness of a world and a generation, just as the foreigners who came to lend their support to the young country by teaching or contributing expertise. Some decided to remain and start families there. The intellectual world following independence saw mixed marriages and other affinities above and beyond those that Kazem Daghestani described in his Syrian milieu of the 1930s. New alliances were being testing; frontiers being crossed. The atmosphere was by no means avant-gardist, but simply worldly.

The question of language is a sensitive one in the region and must be addressed, probably even more so in North Africa than in the Middle East. The question of readership is key, of course. Kazem wrote in French in order to obtain his diploma, but afterwards he worked as a translator, contributing to various journals and introducing, among others, Durkheim's thought to his region. Nazira wrote in Arabic, as her project dictated. But her use of the Arabic language does not close her off into a "local" reality. Rather, her work is a perpetual comparison of European and Arabic spaces: her work created constant opposition between "veiled" and "unveiled" worlds, and the result was an uncritical conception of modernity as development and transparency. Her familiarity with, and high commendations of French culture earned her no little reproach. And the fact that she attended the Lycée français in Beirut was not forgotten though she mastered Arabic perfectly. More than a

\footnotetext{
${ }^{48}$ Butler (2004).

${ }^{49}$ I am thinking in particular of his Reflections on Exile (Said, 2002).
} 
linguistic label, her ties to French were a social distinction. And as soon as she flattered France in Lebanon, it became the sign of her betrayal.

The question of language raises further new questions surrounding the circulation of texts and thought both inside and outside the region. The perception of the use of European languages has significantly changed over the course of the $20^{\text {th }}$ century, and this phenomenon must be historicized and include careful study of the conditions of this circulation how thought is both produced and conveyed. We need to consider nodal points of intellectual mobility such as universities, international book fairs, translation projects or trade unions. To return to Hourani's questions in "How Should We Write the History of the Middle East?" it would make it easier, if we conceived of it, simply enough, as the world - the global space that people and ideas from the Middle East have ventured. ${ }^{50}$

\footnotetext{
${ }^{50}$ Indeed, Hourani reflects lengthily on the question of the definition of the space we call the "Middle East", in Hourani in IJMES (1991: 126-128).
} 